\title{
MENINGKATKAN MOTIVASI DAN HASIL BELAJAR PADA MATERI REAKSI REDOKS DAN TATA NAMA SENYAWA MENGGUNAKAN MODEL ROTATING TRIO EXCHANGE (RTE) BERBANTUAN MEDIA AUDIO VISUAL
}

\author{
Improving Motivation and Learning Outcomes in Redox Reaction \\ Material and Compounds Nomenclature Using Model Rotating Trio \\ Exchange (RTE) Assisted Media Audio Visual
}

Trimah Semi Utami*, Muhammad Kusasi, Iriani Bakti

Program Studi Pendidikan Kimia FKIP Universitas Lambung Mangkurat,

Jl. Brigjend. H. Hasan Basry Banjarmasin 70123 Kalimantan Selatan Indonesia *email: trimahsemiutami@gmail.com

\begin{abstract}
Abstrak. Penelitian tentang penggunaan model pembelajaran rotating trio exchange (RTE) berbantuan media audio visual pada materi reaksi redoks dan tata nama senyawa di kelas X IPA 4 SMAN 8 Banjarmasin bertujuan untuk mengetahui motivasi, hasil belajar, dan respon peserta didik. Penelitian menggunakan rancangan penelitian tindakan kelas dengan 2 siklus. Instrumen penelitian berupa tes dan nontes. Data dianalisis dengan Teknik analisis kuantitatif dan analisis kualitatif. Hasil penelitian menunjukkan bahwa (1) terjadi peningkatan motivasi peserta didik dari kategori cukup tinggi menjadi tinggi, (2) terjadi peningkatan hasil belajar aspek pengetahuan sebesar $17 \%$ dengan rata-rata hasil belajar siklus I sebesar 59\% (tidak tuntas) dan pada siklus II sebesar $76 \%$ (tuntas), terjadi peningkatan hasil belajar aspek sikap peserta didik dari predikat cukup menjadi baik, dan (3) peserta didik memberikan respon positif terhadap pembelajaran menggunakan model pembelajaran RTE berbantuan media audio visual pada materi reaksi redoks dan tata nama senyawa.
\end{abstract}

Kata kunci: motivasi, sikap, pengetahuan, model pembelajaran $R T E$

\begin{abstract}
Research on the use of learning model rotating trio exchange (RTE) using the media audio visual material on redox reactions and nomenclature of compounds in class X IPA 4 SMAN 8 Banjarmasin to find out the motivation, the learning outcomes, and the response of the learners. The research of using class actions research design with a 2 cycle. Research instrument in the form of tests and nontests. Data anlyzed with techniques of quantitative analysis and qualitative analysis. The results showed that (1) an increase in the motivation of learners from high enough into the high category, (2) an increase in the results of the learning aspect of knowledge by $17 \%$ with the average results of the learn cycle I amounted tto 59\% (not completely) and cycle II amounted to $76 \%$ (completely) and increase in the results of the learning aspect of the attitude of the learners of the predicate simply being good, and (3) students give positive response towards learning using learning model RTE assisted media audio visual on redox and nomenclature of compounds.
\end{abstract}

Keywords: motivation, attitude, knowledge, learning model RTE

\section{PENDAHULUAN}

Proses pembelajaran memegang peranan penting dalam menghasilkan kualitas lulusan. Disinilah peran pendidik yang sebenarnya, bagaimana ia dapat lebih memudahkan yang sulit dan mentransformasikan pengetahuan kepada peserta didik.

Copyright $\odot$ JCAE-Jurnal Tugas Akhir Mahasiswa, e-ISSN 2613-9782

Program Studi Pendidikan Kimia FKIP Universitas Lambung Mangkurat 
Proses pembelajaran harus menempatkan peserta didik sebagai subjek belajar, semakin besar keterlibatan dalam pembelajaran, maka semakin besar baginya untuk mengalami proses belajar. Ilmu yang mempelajari sifat, struktur materi disertai perubahan materi dan energi yang menyertainya secara umum didapatkan dari hasil eksperimen dan penalaran adalah kimia (Nuryanti, dkk, 2014). Materi reaksi reduksi oksidasi merupakan materi yang memerlukan pemahaman sekaligus hafalan (Nurhayati, dkk, 2013).

Berdasarkan pengamatan lapangan pada saat melakukan praktik pengajaran lapangan (PPL) di SMAN 8 Banjarmasin, terdapat beberapa kelemahan saat proses pembelajaran yaitu peserta didik kurang menyukai mata pelajaran kimia karena dianggap banyak menghitung dan tidak mudah memahami konsep yang dijelaskan oleh pendidik. Sehingga dalam mempelajari kimia, peserta didik cenderung hanya mendengarkan dan mencatat yang pendidik sampaikan. Kemudian, peserta didik mengerjakan atau menyelesaikan tugas dengan menyalin jawaban temannya dan terbiasa mengandalkan teman yang kemampuannya lebih tinggi dalam menyelesaikan tugas pada saat diskusi kelompok. Selain itu, sebagian peserta didik masih tidak percaya diri mengemukakan pendapatnya di depan kelas. Sehingga, peserta didik yang sama yang selalu mengemukakan pendapatnya setiap kali pembelajaran berlangsung. Jam pelajaran di waktu siang hari membuat peserta didik tidak dapat memfokuskan diri pada pembelajaran.

Rasa ingin tahu itu sendiri merupakan salah satu pendorong untuk peserta didik memberikan perhatiannya dalam pembelajaran. Motivasi yang rendah untuk mengikuti proses pembelajaran yang mengakibatkan kurangnya akivitas peserta. Data ketuntasan belajar yang didapatkan dari sekolah tersebut untuk reaksi didik di kelas, sehingga hasil belajar yang diinginkan tidak sesuai dengan yang diharapkan (Nurhayati, dkk, 2013). redoks sebesar 20,09\% dari total persentase empat kelas. Hal ini menunjukkan bahwa penguasaan pada materi tersebut belum optimal dan motivasi peserta didik yang masih rendah. Berdasarkan permasalahan tersebut, hendaknya pendidik menerapkan model pembelajaran yang kreatif dan inovatif yang dapat meningkatkan motivasi belajar yang nantinya akan berdampak positif pada hasil belajar peserta didik.

Model yang dapat diterapkan adalah model pembelajaran kooperatif tipe rotating trio exchange (RTE) berbantuan media audio visual. Penerapan model tersebut diharapkan dapat menghilangkan kejenuhan peserta didik saat proses pembelajaran dan peserta didik dapat mengembangkan kepercayaan diri dengan mengemukakan pendapat, melatih tanggung jawab dalam kerja kelompok dengan siswa lainnya, serta dengan adanya media audio visual diharapkan dapat memotivasi peserta didik dalam belajar sehingga memberikan kepuasan tersendiri saat pembelajaran berlangsung.

\section{METODE PENELITIAN}

Rancangan yang digunakan dalam penelitian ini adalah penelitian tindakan kelas, dengan subjek penelitian peserta didik kelas X IPA 4 SMAN 8 Banjarmasin. Penelitian dilaksanakan dalam dua siklus, setiap siklus terdiri dari tahapan-tahapan seperti perencanaan tindakan, pelaksanaan, pengamatan, serta perenungan. Instrumen yang digunakan yaitu instrumen tes berupa tes hasil belajar aspek pengetahuan dalam bentuk soal pilihan ganda sebanyak 15 butir soal, dan instrumen nontes berupa lembar observasi sikap, angket motivasi, serta angket respon peserta didik. Lembar observasi sikap peserta didik terdiri dari 4 aspek penilaian yang dinilai oleh observer. Angket motivasi yang digunakan berisi 28 pernyataan sesuai dengan motivasi model ARCS (Attention, Relevance, Confidence, Satisfaction), sedangkan angket respon terdiri dari 
10 peryataan.

Analisis motivasi peserta didik bertujuan untuk melihat perkembangan motivasi peserta didik selama mengikuti proses pembelajaran menggunakan model pembelajaran RTE berbantuan media audio visual. Penskoran untuk angket motivasi peserta didik diberi skor 1 sampai 5. Motivasi peserta didik diskor dengan menggunakan rumus sebagai berikut:

$$
\text { Motivasi }=\frac{\Sigma \text { total skor }}{\Sigma \text { pernyataan }}
$$

Klasifikasi kategori skor motivasi dapat dilihat pada tabel 1.

Tabel 1. Kategori skor motivasi peserta didik

\begin{tabular}{cc}
\hline Skor & Kategori \\
\hline $1,00-1,49$ & Sangat Rendah \\
$1,50-2,49$ & Rendah \\
$2,50-3,49$ & Cukup Tinggi \\
$3,50-4,49$ & Tinggi \\
$4,50-5,00$ & Sangat Tinggi \\
\hline
\end{tabular}

Analisis pengetahuan peserta didik digunakan untuk menentukan keberhasilan peserta didik dalam memahami materi reaksi redoks dan tata nama senyawa yang ditunjukkan dengan jumlah peserta didik yang menjawab benar pada setiap butir tes yang diujikan. Berdasarkan KKM yang ditentukan oleh SMAN 8 Banjarmasin, secara individual yaitu peserta didik dikatakan tuntas apabila mendapatkan nilai lebih dari atau sama dengan 70 . Selanjutnya, hasil belajar aspek sikap peserta didik dikatakan meningkat apabila tergolong ke dalam predikat baik.

Penskoran untuk penilaian observasi sikap siswa terdapat skor terendah 1 dan tertinggi yakni 4. Kemudian, untuk angket respon dirancang mengggunakan skala likert dengan rentang 1 sampai 5. Hasil respon peserta didik dikatakan positif jika total persentase pesertadidik yang memilih sangat setuju dan setuju tiap butir pernyataan akumulasinya lebih besar dari jumlah persentase peserta didik yang menjawab raguragu, tidak setuju, dan sangat tidak setuju.

\section{HASIL PENELITIAN DAN PEMBAHASAN}

\section{Motivasi Belajar Peserta Didik}

Hasil skor motivasi peserta didik berdasarkan angket dari 28 pernyataan sesuai pendapat peserta didik pada siklus I sebesar 3,32 dengan kategri cukup tinggi dan pada siklus II sebesar 4,11 dengan kategori tinggi. Adapun perbandingan motivasi peserta didik dari setiap siklus terlihat pada gambar 1.

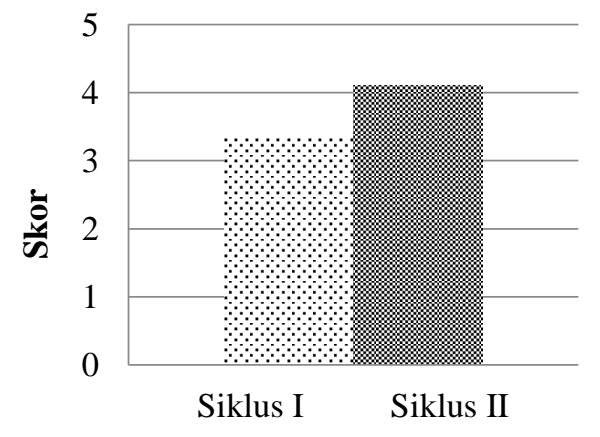

Gambar 2. Perbandingan skor motivasi siswa siklus I dan siklus II 
Peningkatan motivasi dari setiap siklus menunjukkan bahwa peserta didik merasakan nyaman dan puas dengan penerapan model pembelajaran RTE berbantuan media audio visual. Penggunaan metode atau cara mengajar guru yang tepat yang dilengkapi dengan media audio visual maka peserta didik akan mudah memahami materi pelajaran dan akan termotivasi dalam memahami materi pelajaran. Manfaat media audio visual adalah sebagai media penunjang untuk menarik perhatian peserta didik, sehingga dapat menumbuhkan motivasi belajar (Sumarni, dkk, 2009).

Perbandingan skor motivasi peserta didik tiap indikator ARCS dari setiap siklus dapat dilihat pada gambar 2 .

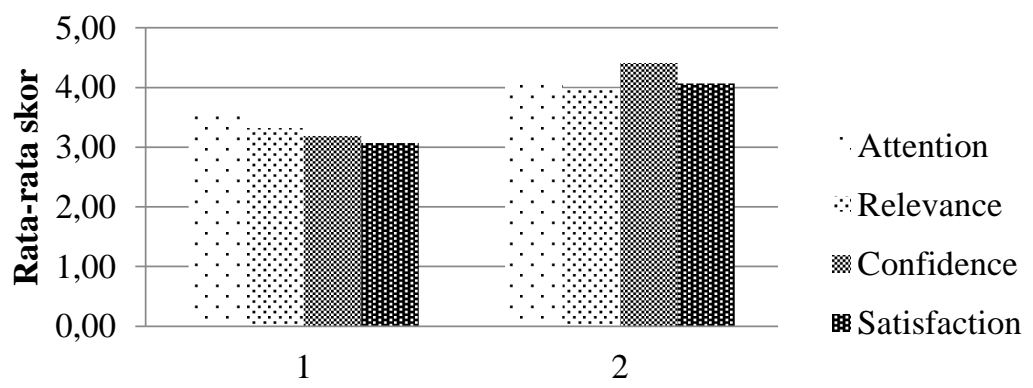

Aspek motivasi

\section{Gambar 2. Perbandingan skor motivasi siklus I dan siklus II tiap indikator ARCS}

Pertama kali yang harus dilakukan untuk memotivasi peserta didik adalah menarik perhatian peserta didik itu sendiri. Menarik perhatian peserta didik dapat dilakukan dengan memberikan kejadian atau permasalahan sederhana yang dapat merangsang peserta didik, sehingga memicu rasa penasaran yang lebih dalam akan sesuatu, terutama saat dipresentasikan pada awal pembelajaran (Kurt dan Kecik, 2017).

Perhatian itu sendiri dapat berarti sama dengan konsentrasi. Adanya rasa ingin tahu membuat peserta didik akan memperhatikan apa yang sedang dipelajari (Wilujeng, dkk, 2016). Hal ini dapat timbul dengan adanya dorongan dari peserta didikdan adanya bantuan guru melalui kegiatan apersepsi sehingga perhatian dapat terpusat pada pembelajaran. Keingintahuan peserta didik memunculkan keberanian siswa untuk menanggapi atau mengemukakan pendapat pada saat pembelajaran. Efek dari keberanian peserta didik tersebut dapat mengembangkan percaya diri peserta didik itu sendiri. Relevansi juga bagian bagian terpenting dalam meningkatkan motivasi peserta didik. Jika peserta didik merasa pelajaran yang dipelajari terkait dalam kehidupan sehari-hari dan bermanfaat maka ini merupakan motivasi dalam penguatan belajar. Hal ini sejalan dengan pernyataan Sardiman (2012) bahwa motivasi peserta didik akan meningkat dan berkembang apabila mereka merasakan manfaat materi yang mereka pelajari di kehidupan mendatang.

Indikator percaya diri memiliki skor tertinggi pada siklus II, ini menunjukan usaha pendidik dalam memberikan bimbingan dan penguatan kepada peserta didik, telah mampu merubah siswa yang pasif menjadi aktif. Untuk dapat mempertahankan motivasi peserta didik juga diperlukan kepuasan. Indikator motivasi juga mengalami peningkatan. Wilujeng, dkk (2016) berpendapat bahwa aspek kepuasan merupakan aspek yang menunjukkan perasaan gembira dan perasaan puas terhadap pembelajaran. Aspek ini dapat muncul dalam diri peserta didik jika ia merasa dihargai atas kerja 
kerasnya dan memperoleh penghargaan sesuai dengan apa yang menjadi tujuannya, baik itu penghargaan yang berupa nilai atau komentar.

\section{Hasil Belajar Aspek Pengetahuan}

Secara keseluruhan pada siklus I dan siklus II terjadi peningkatan ketuntasan hasil belajar aspek pengetahuan peserta didik secara keseluruhan pada siklus I sebesar $59 \%$, sedangkan pada siklus II sebesar $76 \%$. Perbandingan ketuntasan hasil belajar aspek pengetahuan setiap siklus dapat dilihat pada gambar 3 .

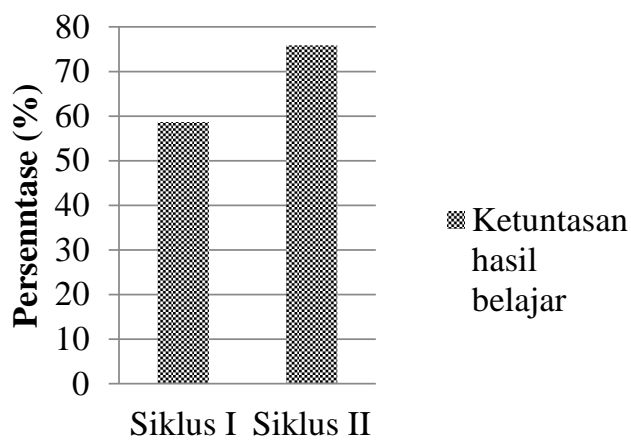

\section{Gambar 3. Perbandingan ketuntasann hasil belajar aspek pengetahuan setiap siklus}

Hasil tes pada siklus I terdapat dua indikator yang masih tidak tuntas yaitu indikator $1(67 \%)$ dan indikator $3(69 \%)$, sedangkan indikator $2(76 \%)$ telah tuntas. Tidak tercapainya ketuntasan pada indikator 1 dan indikator 3 dikarenakan peserta didik masih bingung dan belum bisa membedakan konsep reaksi redoks sehingga banyak peserta didik yang keliru dalam menjawab soal.

Perbaikan dilakukan pada siklus II yang menyebabkan peningkatan kemampuan aspek pengetahuan meningkat. Hasil tes siklus II diperoleh rata-rata persentase per indikator sebesar 76\%. Jika ditinjau dari KKM SMAN 8 Banjarmasin, maka hasilnya sebesar $76 \%$ dengan jumlah peserta didik yang mencapai ketuntasan sebanyak 22 peserta didik dan yang tida tuntas sebanyak 7 peserta didik dengan persentase sebesar $24 \%$.

Penggunaan model pembelajaran RTE berbantuan media audio visual inni dapat membantu meningkatkan hasil belajar peserta didik. Adanya diskusi kelompok dalam menyelesaikan soal pada saat pembelajaran berlangsung memberikan kesempatan baik kepada peserta didik untuk bertukar pikiran/pendapat agar lebih mudah memahami konsep yang diajarkan. Selain itu, media audio visual dapat mendorong peserta didik untuk menggunakan banyak alat indera. Semakin banyak alat indera yang digunakan dalam proses pembelajaran maka akan berpengaruh besar terhadap hasil belajar (Sumarni, dkk, 2009).

\section{Hasil Belajar Aspek Sikap}

Aspek yang diamati pada hasil belajar sikap peserta didik yaitu rasa ingin tahu, tanggung jawab, toleransi, dan teliti yang dinilai dalam setiap pembelajaran berlangsung. Rata-rata hasil belajar sikap peserta didik sebesar 2,27 yang berada dalam predikat cukup, sedangkan pada siklus II meningkat menjadi 3,03 dengan predikat baik. Hal ini menunjukkan bahwa model pembelajaran RTE berbantuan media audio visual yang digunakan telah mendorong diri peserta didik untuk memiliki rasa ingin tahu yang tinggi, bertanggung jawab akan tugasnyadalam sebuah 
kelompok, memiliki toleransi terhadap anggota lainnya dalam menyelesaikan tugas dengan tingkat kesulitan yang bervariasi sehingga menjadi lebih teliti.

Peserta didik yang mendapatkan tantangan soal sulit akan terbentuk usaha belajar dan dalam hal ini juga terbentuk karakter-karakter positif yang mendukung seperti rasa ingin tahu, tanggung jawab, tekun, toleransi, disiplin, jujur dan objektif, mau bekerja sama, demokratis dalam hal memberi dan menerima ide teman lain (Widodo dan Kadarwati, 2013).

\section{Respon Peserta Didik}

Sebagian besar peserta didik memberikan respon positif terhadap model RTE berbantuan media audio visual. Hal ini ditunjukkan dengan banyaknya peserta didik yang memberikan respon setuju dan sangat setuju sebesar $88 \%$.

\section{SIMPULAN}

Berdasarkan hasil penelitian yang telah dilakukan, maka dapat disimpulkan sebagai berikut:

1) Pembelajaran model RTE berbantuan media audio visual dapat meningkatkan motivasi belajar peserta didik.

2) Pembelajaran dengan menggunakan model RTE berbantuan media audio visual dapat meningkatkan hasil belajar aspek pengetahuan yakni sebesar 17\%, dan aspek sikap dengan predikat baik.

3) Pembelajaran menggunakan model RTE berbantuan media audio visual pada materi reaksi redoks dan tata nama senyawa mendapatkan respon positif dari peserta didik.

\section{DAFTAR RUJUKAN}

Kurt, Y.P., Kecik, I. (2017). The Effects of ARCS Motivational Model on Student Motivation to Learn English. European Journal Of Foreign Language Teaching, 2.

Nurhayati, W., Yasmi, A. E., dan Erviyenni. (2013). Penerapan Model Pembelajaran Kooperatif Tipe Rotating Trio Exchange (RTE) Sebagai Upaya Peningkatan Prestasi Belajar Siswa pada Pokok Bahasan Reaksi Reduksi Oksidasi di Kelas X SMA Negeri 2 Pekanbaru. Riau: Universitas Riau.

Nuryanti, Ni Wayan, Sihaloh, M., dan Lukum, A. (2014). Menggunakan Media Kartu pada Materi Reaksi Reduksi di Kelas X-1 SMA Negeri 1 Tapa. Goronntalo: UNG.

Sumarni, W., Soeprodjo, Puji R.K. (2009). Efektivitas Penerapan Metode Kasus Menggunakan Media Audio Visual Terhadap Hasil Belajar Kimia Siswa SMA. Jurnal Inovasi Pendidikan Kimia, 3(1).

Widodo, T., \& Kadarwati, S. (2013). Higher Order Thinking Berbasis Pemecahan Masalah untuk Meningkatkan Hasil Belajar Berorientasi Pembentukan Karakter Siswa. Cakrawala pendidikan No.1.

Wilujeng, P.D., Rusman, Nasir, M. (2016). Penerapan Model ARCS untuk Meningkatkan Ketuntasan Belajar Siswa pada Materi Hidrokarbon SMAN 1 Baitussalam. Jurnal Ilmiah Mahasiswa Pendidikan Kimia (JIMPK),1(4). 